\title{
Indonesia Language Learning and Environtment
}

\author{
Novira Amir/18016203 \\ noviraamirr@gmail.com
}

Teacher need to include environtment education on Indonesia language learning. As Ramadhan, Sukma and Indriyani (2019) said, the level of students' knowledge and awareness of the environment is still low so that teachers need to increase knowledge about the environment and disaster mitigation in order to design language learning with environmental education and disaster mitigation. The low knowledge of students about the environment is very concerning, considering that students are the next generation who must be able to protect the environment. Students should have experience in taking initiatives related to the need for closeness in the field of global challenges in society. Indonesia language learning can increase student awarness of the problem on their environtment. In line with the questionnaire distributed to 36 students from UNP, Unand, Undip, UGM, Unila, IPB, STIS, Universitas Perintis Indonesia, PNP, Universitas Syiah Kuala, Unisba, dan Binus University, on item 4 , agree $(55,6 \%)$, strongly agree $(44,4 \%)$, disagree $(0 \%)$, and strongly disagree $(0 \%)$ agree that Indonesia language learning with environtment-based could increase student awarness of environtment problem.

Environmental education focuses on environmental and social issues, and is considered fundamental if society wants to instill its citizens with a sense of environmental responsibility, environmental ethics, and ecological awareness so that environmental education can be integrated into the learning process. Environmental education can be considered as key because it encourages individuals to protect the environment from potential local and existing global environmental challenges (Sukma, Ramadhan, and Indriyani, 2020). In line with the questionnaire distributed to 36 students from UNP, Unand, Undip, UGM, Unila, IPB, STIS, Universitas Perintis Indonesia, PNP, Universitas Syiah Kuala, Unisba, dan Binus University, on item 3, agree (55,6\%), disagree (30,6\%), strongly agree $(13,9 \%)$, and strongly disagree $(0 \%)$ that Indonesia language learning with environtment-based could make students are moved to care about their environment. On item 10, about $64,4 \%$ agree, $27,8 \%$ strongly agree, 2,8\% disagree and 0\% strongly disangree that Indonesia language learning with environtment-based could increase student's sensitivity to values and morals 
The application of Indonesian language learning related to environment on Indonesian language skills, which one of them is reading. The main factor that causes problems on reading comprehension is the ineffective reading learning process. Teacher is the main component to make the strategies and effectifness on learning process (Sari, Ramadhan and Rasyid, 2018). Teachers can use reading comprehension about environment so that students focus on environmental learning. By focusing Indonesian language learning on the environment, efforts to raise student's awareness so that they care about the environment will be embedded in students mind.

There is a lot of Indonesia language learning from our environtment. For example, region naming. As Amin, Ramadhan and Ermanto (2013) said, the origins of regional names, customary law, and various kinds of wisdom that are poured out through various myths, tales, tombos, and histories. These origins can be used as learning for students, for example when reading legend texts, short story texts and others. The text can be converted into various other text genres such as drama texts, poetry and others. Using examples in the environment will make students more familiar with learning Indonesian. In line with the questionnaire distributed to 36 students from UNP, Unand, Undip, UGM, Unila, IPB, STIS, Universitas Perintis Indonesia, PNP, Universitas Syiah Kuala, Unisba, dan Binus University, on item 6, strongly agree $(47,2 \%)$, agree $(47,2 \%)$, disagree $(5,6 \%)$ dan strongly disagree $(0 \%)$ that environtment could be student's inspiration on Indonesia language lerning.

Another example of the application on Indonesia language lerning that environtment based is explanatory text, which contains an explanation of the processes associated with natural, social, scientific, cultural phenomena. Explanatory text comes from the author's question regarding "why" and "how" a phenomenon occurs. Explanatory text aims to explain the formation process or activities related to natural, social, scientific, or cultural phenomena. (Fitri, Ramadhan, and Afnita, 2018). In order to understand and be able to produce explanatory texts, we need to observe our environment. By involving the environment, we will understand better about learning Indonesian. And even helping students to understand their surroundings. In line with the questionnaire distributed to 36 students from UNP, Unand, Undip, UGM, Unila, IPB, STIS, Universitas Perintis Indonesia, PNP, Universitas Syiah Kuala, Unisba, dan Binus University, on item 8, 75\% agree, 13,9\% strongly agree, $11,1 \%$ disagree and $0 \%$ strongly disagree that the ability of student observation of the environment is needed in Indonesian language learning. On item 2, agree (55,65\%), strongly 
agree $(25 \%)$, disagree $(19,4 \%)$ and strongly disagree $(0 \%)$ that Indonesian language learning could help student to be more observant on their environtment.

The use of the environment as Indonesian language learning is not only carried out when learning at school. Suardi, Ramadhan, and Asri (2019) said language acquisition in children in the phonological aspect is influenced by environmental factors, especially family, this is indicated by the large number of vocabulary they get in the family environment and around them. So its not a new thing to used environtment on Indonesia language learning, but learn with environtment-based need to utilized optimally, used interesting techniques and methods so that the learning objectives are achieved.

Students' reading attitudes will affect their writing. While learning to read, he also studied how each letter was formed. Likewise, learning to read, the experience of learning to write will also affect writing interest later. Lazy reading may be caused by an unpleasant reading recognition process at school or at home. Forcing a child to read immediately in a short time can affect their reading interest (Sukma, Mahjuddin, and Amelia, 2017). Therefore, teachers need to create a pleasant environment for students so that students do not feel forced to learn Indonesian. By implementing environment-based Indonesian language learning, students can be invited to understand the surrounding environment so that learning feels close to students and students do not feel forced to learn Indonesian. Learning Indonesian language will be a fun activity because learning is carried out by observing the environment around students. In line with the questionnaire distributed to 36 students from UNP, Unand, Undip, UGM, Unila, IPB, STIS, Universitas Perintis Indonesia, PNP, Universitas Syiah Kuala, Unisba, dan Binus University, on item 7, 52,8\% agree, 41,7\% strongly agree, 5,6\% disagree and $0 \%$ strongly disagree that by understanding their surroundings, students can learn Indonesian better because students feel more "relate" to the environment. Students will understand their environment more deeply and understand what is happening around the student's environment.

There are many benefits to be gained by implementing environment-based Indonesian language learning. As Amelia, Sukma and Asma (2015) conduct research on "Pembelajaraan Menulis Laporan Percobaan Dengan Pendekatan Saintifik di Sekolah Dasar" translate as "Learning to Write Experiment Reports with a Scientific Approach in Elementary Schools". The results of this study are motivating students to learn to write in real terms because they collect data from objects or experimental phenomena for which the report will be written, 
students feel challenged to explore their curiosity about natural phenomena, please students because they feel proud to be able to participate in writing activities, and arouse students' interest in writing because they can publish the results of their experiments in written form. In line with the questionnaire distributed to 36 students from UNP, Unand, Undip, UGM, Unila, IPB, STIS, Universitas Perintis Indonesia, PNP, Universitas Syiah Kuala, Unisba, dan Binus University, on item 1, 66,7\% agree, $25 \%$ strongly agree, 8,3\% disagree and $0 \%$ strongly disagree that Indonesia language learning with environment-based are heling student to concecive the environment better. Environmental-based Indonesian learning not only makes students motivated to learn Indonesian, but also motivated to learn the environment.

By carrying out environmental-based Indonesian language learning, it is hoped that there will also be an increase in literacy in the life of Indonesian society. In line with Indriyani, Zaim, Atmazaki and Ramadhan (2019) said that literacy activities in schools create more inclusive literacy practices, we must understand the relationship between literacy practices and discourse, family and community. The point is, learning Indonesian is not only influenced by the environment, but the environment will also affect how the state of learning Indonesian is. If Indonesian language learning is associated with the environment, it will be subconsciously embedded in students that they have an influence on their environment. In line with that, Sukma, Mahyudin, Rahmatina, and Suriani (2019) said that "The ability of teachers to teach speech skills is how teachers present speaking subjects so that learning is meaningful for students." How teachers shape the environment in their class will affect how students learn. The teacher is in control and directs it so that students can make good use of the environment so that learning objectives are achieved.

The results of learning Indonesian based on the environment around students are more satisfying than the results of learning Indonesian which only refer to books, in line with the questionnaire distributed to 36 students from UNP, Unand, Undip, UGM, Unila, IPB, STIS, Universitas Perintis Indonesia, PNP, Universitas Syiah Kuala, Unisba, dan Binus University, on item $5,58,3 \%$ strongly agree, $41,7 \%$ agree, $0 \%$ disagree dan $0 \%$ strongly disagree with that statement. On the top of that, on item 9 , agree $(61,1 \%)$, strongly agree $(30,6 \%)$, disagree $(8,3 \%)$ and strongly disagree $(0 \%)$ that Indonesia language learning with environtment-based must be implemented in all school. Seeing the importance and the many benefits that can be obtained from environment-based Indonesian language learning, it is highly recommended to implement environment-based Indonesian language learning. 


\section{REFERENCE}

Amelia, Rizky, Elfia Sukma, dan Nur Asma. (2015). Pembelajaraan Menulis Laporan Percobaan Dengan Pendekatan Saintifik di Sekolah Dasar. Prosiding Seminar Nasional Jurusan PGSD FIP UNP. Vol.1, No.1

Amin, Irzal, Syahrul R, dan Ermanto. (2013). CERITA RAKYAT PENAMAAN DESA DI KERINCI: Kategori dan Fungsi Sosial Teks. Jurnal Bahasa, Sastra dan Pembelajaran. Vol. 1, No. 1

Fitri, Margian Mulya, Syahrul R., Afnita. (2018). Pengaruh Model Discovery Learning Berbantuan Media Gambar Berseri Terhadap Keterampilan Menulis Teks Eksplanasi Siswa Kelas VIII SMP Negeri 25 Padang. Jurnal Pendidikan Bahasa dan Sastra Indonesia, Vol. 1 No. 7

Indriyani, Vivi, M. Zaim, Atmazaki, dan Syahrul Ramadhan. (2019). Literasi Baca Tulis Dan Inovasi Kurikulum Bahasa. KEMBARA: Jurnal Keilmuan Bahasa, Sastra, dan Pengajarannya. Vol. 5, No. 1

Ramadhan, Syahrul, Elvia Sukma dan V Indriyani. (2019). Environmental education and disaster mitigation through language learning. IOP Conf. Series: Earth and Environmental Science 314012054

Sari,Yuliana, Syahrul R, dan Yulianti Rasyid. (2018). Hubungan Antara Keterampilan Membaca Pemahaman Dengan Keterampilan Menulis Teks Laporan Hasil Observasi Siswa Kelas X SMK Negeri 3 Padang. Jurnal Pendidikan Bahasa dan Sastra Indonesia. Vol. 7, No.3

Suardi, Indah Permatasari, Syahrul R, dan Yasnur Asri. (2019). Pemerolehan Bahasa Pertama pada Anak Usia Dini. Jurnal Obsesi : Jurnal Pendidikan Anak Usia Dini. Vol. 3, No. 1

Sukma, Elfia, R. Mahyudin, Rahmatina, dan A.Surian. (2019). Problems In Oral Language Teaching In Primary School. Advances in Social Science, Education and Humanities Research. Vol. 301

Sukma, Elfia, Ritawati Mahjuddin, dan Rizky Amelia. (2017). Literacy Media Development in Improving Reading and Writing Skill of Early Class Students in Elementary School Padang Utara Padang. Advances in Social Science, Education and Humanities Research. Vol. 118

Sukma, Elfia, S. Ramadhan dan V Indriyani. (2020). Integration of environmental education in elementary schools. Journal of Physics: Conference Series 1481 


\section{ATTACHMENT}

\section{Tabel 1}

Questionnaire on the Relationship of Indonesian Language Learning with the Environment

\begin{tabular}{|c|l|c|c|c|c|}
\hline No. & \multicolumn{1}{|c|}{ Question } & SA & A & D & SD \\
\hline 1. & $\begin{array}{l}\text { Indonesia language learning with environment-based } \\
\text { are heling student to concecive the environment better. }\end{array}$ & $25 \%$ & $\mathbf{6 6 , 7 \%}$ & $8,3 \%$ & - \\
\hline 2. & $\begin{array}{l}\text { Indonesian language learning could help student to be } \\
\text { more observant on their environtment. }\end{array}$ & $25 \%$ & $\mathbf{5 5 , 6 \%}$ & $19,4 \%$ & - \\
\hline 3. & $\begin{array}{l}\text { Indonesia language learning with environtment-based } \\
\text { could make students are moved to care about their } \\
\text { environment. }\end{array}$ & $13,9 \%$ & $\mathbf{5 5 , 6 \%}$ & $30,6 \%$ & - \\
\hline 4. & $\begin{array}{l}\text { Indonesia language learning with environtment-based } \\
\text { could increase student awarness of environtment } \\
\text { problem. }\end{array}$ & $44,4 \%$ & $\mathbf{5 5 , 6 \%}$ & - & - \\
\hline $\begin{array}{l}\text { The results of learning Indonesian based on the } \\
\text { environment around students are more satisfying than } \\
\text { the results of learning Indonesian which only refer to } \\
\text { books }\end{array}$ & $\mathbf{5 8 , 3 \%}$ & $41,7 \%$ & - & - \\
\hline $\mathbf{6 .}$ & $\begin{array}{l}\text { Environtment could be student's inspiration on } \\
\text { Indonesia language lerning. }\end{array}$ & $\mathbf{4 7 , 2 \%}$ & $47,2 \%$ & $5,6 \%$ & - \\
\hline 7. & $\begin{array}{l}\text { By understanding their surroundings, students can } \\
\text { learn Indonesian better because students feel more } \\
\text { "relate" to the environment. }\end{array}$ & $41,7 \%$ & $\mathbf{5 2 , 8 \%}$ & $5,6 \%$ & - \\
\hline $\mathbf{8 .}$ & $\begin{array}{l}\text { The ability of student observation of the environment } \\
\text { is needed in Indonesian language learning }\end{array}$ & $13,9 \%$ & $\mathbf{7 5 \%}$ & $11,1 \%$ & - \\
\hline $\mathbf{9 .}$ & $\begin{array}{l}\text { Indonesia language learning with environtment-based } \\
\text { must be implemented in all school. }\end{array}$ & $30,6 \%$ & $\mathbf{6 1 , 1 \%}$ & $8,3 \%$ & - \\
\hline $\mathbf{1 0 .}$ & $\begin{array}{l}\text { Indonesia language learning with environtment-based } \\
\text { could increase student's sensitivity to values and } \\
\text { morals }\end{array}$ & $27,8 \%$ & $\mathbf{6 4 , 4 \%}$ & $2,8 \%$ & - \\
\hline $\begin{array}{l}\text { The number of respondents was 36 students from UNP, Unand, Undip, UGM, Unila, } \\
\text { IPB, STIS, Universitas Perintis Indonesia, PNP, Universitas Syiah Kuala, Unisba, dan } \\
\text { Binus University. }\end{array}$ & & & - \\
\hline
\end{tabular}

Note:

SA : Strongly Agree

A : Agree

D : Disagree

SD : Strongly Disagree 